\title{
THE ARRIVAL OF THE SMARTEST: IN FAVOUR OF A PLURALISTIC ACCOUNT OF THE EVOLUTION OF COGNITION
}

\author{
[A CHEGADA DO MAIS INTELIGENTE: A FAVOR DE UMA EXPLICAÇÃO PLURALISTA DA \\ EVOLUÇÃO DA COGNIÇÃO]
}

Giorgio Airoldi * UNED, Spain

\begin{abstract}
The great advances of the last decades both in cognitive theories and in evolutionary biology have not yet fully merged. Most evolutionary hypotheses around the mind still rely on classical cognitivism, while most theories of cognition still look for adaptive explanations. We believe that the merging of novel cognitive theories into a pluralistic account can greatly improve our understanding of both what cognition is and how it evolved.

KEYWORDS: evolutionary theories; adaptationism; extended evolutionary synthesis; theories of mind; cognitivism; $4 \mathrm{E}$ cognition
\end{abstract}

Resumo: Os grandes avanços das últimas décadas, tanto nas teorias cognitivas quanto na biologia evolutiva, ainda não se fundiram totalmente. A maioria das hipóteses evolucionárias em torno da mente ainda se apóia no cognitivismo clássico, enquanto a maioria das teorias da cognição ainda busca explicações adaptativas. Acreditamos que a fusão de novas teorias cognitivas em uma explicação pluralística pode melhorar muito nossa compreensão do que é a cognição e de como ela evoluiu.

Palavras-Chave: teorias evolucionistas; adaptacionismo; síntese evolutiva estendida; teorias da mente; cognitivismo; cognição 4E

\section{INTRODUCTION}

Tn a science fiction tale I read long ago, humanity suffers a wave of mutations and a special police eliminates their bearers to avoid the spreading of the evil genes. Things get out of control when a new mutant type appears with very low IQ, but hypnotically handsome and able to foresee five minutes into the future. His irresistible beauty ensures him a high fitness, his foreseeing ability guarantees his survival, as he can anticipate and escape all traps. The mutation spreads and humanity walks toward a future of aesthetic idiocy...

This tale reflects an intuitive fact: natural selection does not, in itself, ensure a path of increasing phenotypic complexity, less so with regards to cognition. Intelligence might be an asset, but whether always the best asset in selective terms is open to discussion. The tale also talks about cognition: foreseeing into the future can be interpreted as a form of intelligence rather than a sensorial ability, in which case the selected mutant is the fittest and the smartest at the same time. But, what if human

* PhD, Dept. of Logic, History and Philosophy of Science, UNED, Madrid (Spain). Email: gairoldi1@icloud.com.Orchid id: 0000-0003-1535-674Xi, UNED, Spain 
cognition resulted from processes that have nothing to do with selection of the best adapted? Could the smartest and the fittest do not always necessarily coincide?

The last decades have witnessed a flourishing of proposals of pluralistic, nonselective accounts of evolution, that consider selection as an important but not unique nor paramount source of evolutionary novelties; and, at the same time, the appearance of theories of embedded, scaffolded and extended cognition, which go beyond classical cognitivism. While representationalism naturally fits with adaptationism (for they share ideas such as externalism and optimization), it is striking that 4E proposals often justify the appearance and fixation of cognitive abilities in terms of their problem-solving features. Likewise, it is curious that pluralistic accounts of evolution often recur to representational theories of mind.

In this paper we claim that revolutionary hypotheses around cognition should take advantage of the revolutionary proposals around non-selective evolution mechanisms. In section 2, we briefly summarize the main non-cognitivist debates around what cognition is. In section 3, we list some of the proposals regarding nonselective sources of evolutionary novelties. In section 4, we analyse the adaptationist basis of much of the literature around the evolution of cognition, and suggest some examples of the more fruitful pluralistic approach. In section 5, we conclude.

\section{WHAT DO WE TALK ABOUT WHEN WE TALK ABOUT COGNITION?}

There is little consensus around the question of what cognition is. In this section, we introduce the main theories of mind, starting from the cognitivist tradition, which places all cognition within a computer-like brain, to continue with more novel approaches, which interpret cognition as an ability distributed among brain, body and environment. We can identify many dimensions in this classification, e.g. the role played by representations in cognition, the physical area where cognition takes place and the degree of commitment to functionalism. This last dimension is the natural bridge between theories of mind and adaptationist evolutionary explanations.

At one extreme of the classification, cognitivism sees cognition as the processing of representations taking place within the neural connections of the brain (Adams and Aizawa 2001). Neisser (1967) was probably the first to define cognition as the processes, occurring in the brain, of processing inputs gathered through the senses into outputs transmitted to the motor system. This 'brain-bound' approach is strongly internalist and functionalist - features that suit very well with adaptationist accounts of its evolution - , as it considers intelligence as the ability to solve problems and the brain as a computer that processes symbols according to syntactic rules: an idea behind the first essays on Artificial Intelligence (Reeke and Edelman 1988). The purely physical nature of the handled representations entails the problem of how these acquire their semantic content. Adams and Aizawa (2010) solve the issue by considering only representations with internal, non-derivative content, located uniquely in the brain. These are representations whose meaning is not defined by social norms nor can be modified socially (like the meaning of the colour red in a traffic light can), and that cannot be manipulated directly.

Several theories of the mind depart from radical internalism by granting an explanatory role in cognition to the body and its representations. These theories are usually collected under the umbrella concept of 'embodied' (e.g. Clark 2007, Gallagher 2005), to underline their compromise with a distributed and not 'brain-bound' cognition. The most radical embodied positions (also known as enactivist) get rid of 
representations as 'mirrors of the world' by considering that cognitive processes entail the action of the body 'in' and 'on' the environment: representations are 'actionoriented' and cognition is grounded upon sensorimotor coordination (Clark 2011, Chemero 2009, Hutto and Myin 2012). The strong link between perception and action limits the need for mediating computational steps: intelligence becomes a relational property, the ability of a system of assuming a proper configuration within a dynamic environment (Brooks 1991). This approach (known as connectivism) seems to fit naturally to the brain, where no central processor is to be found and cognition is distributed among massive quantities of interconnections. Connectivism does not rely on sequential logic and thus avoids the bottlenecks of symbolic processing that hinders cognitivist accounts: it can explain cognitive capacities such as rapid recognition, associative memory and categorical generalization (Varela et al. 2016). Cognitivism and connectionism can be interpreted as descriptions of a system at different levels of analysis, and connectionism could be the way the human brain physically implements a symbol-processing cognitive system: Chang (2002) has produced a connectionist model able to produce sentences, while Smolensky (1990) has proposed an integrated connectionist/symbolic cognitive architecture (ICS). Recently, Turing machines running on neural networks have been successfully tested for simple tasks (Graves et al. 2014). Different architectures can coexist in a cognitive system, and each architecture can have a different evolutionary history: function and representation can emerge from complex networks.

Externalist positions (also known as embedded) grant an active role in cognition to the environment. Weak externalism considers that the latter just supply inputs and outputs to cognitive processes, without being a constitutive part of them (Rupert 2004, Wheeler 2010), and underlines the differences between external and internal states, for example between internal and external memory. In the scaffolded mind hypothesis, the environment takes a stronger causal role in cognition. Embedded cognition hypotheses have been tested through neural network simulations: neural networks can improve their efficiency by relying on external memory (Greve et al. 2016).

In the extended mind hypothesis, the most extreme externalist position, the frontiers between brain, body and physical and cultural environment disappear with regards to cognitive states and processes, as all these elements are inter-linked through systemic relationships (Wilson 2004, Clark and Chalmers 1998, Clark 2011). Out of the body elements showing portability, availability, typical and uncritical use, and easiness of access can fuel human cognition and make it possible in the first place (Clark 2010). Such characteristics (that constitute the 'parity principle') entail some kind of functionalism - weak according to Chalmers (Clark 2011), strong according to Wheeler (2008) - , as mental states are such because of their function and not of their localization (Bechtel 1988).

The extended mind hypothesis has been extensively criticized for being too external and too functionalist; but we mention here the opposite critique by Sterelny (2018) that considers it too individualist. The environmental and cultural resources incorporated within the individual cognitive system are not produced by the individual but are available through the niche the individual lives in. Otto's notebook and Otto's language were not conceived and created by Otto. Extended cognition, according to Sterelny (2010), is a special case of niche cognition. Living beings and environments constitute a physical, social, technological and cultural hybridization, where not only human cognition, but the whole human being is extended into the environment, as with digestion's dependence on external cooking techniques (for a critique, Vecchi 2019). Agents modify the environment and the environment modifies the agents in an 
interconnected causal network.

Table 1 summarizes these positions.

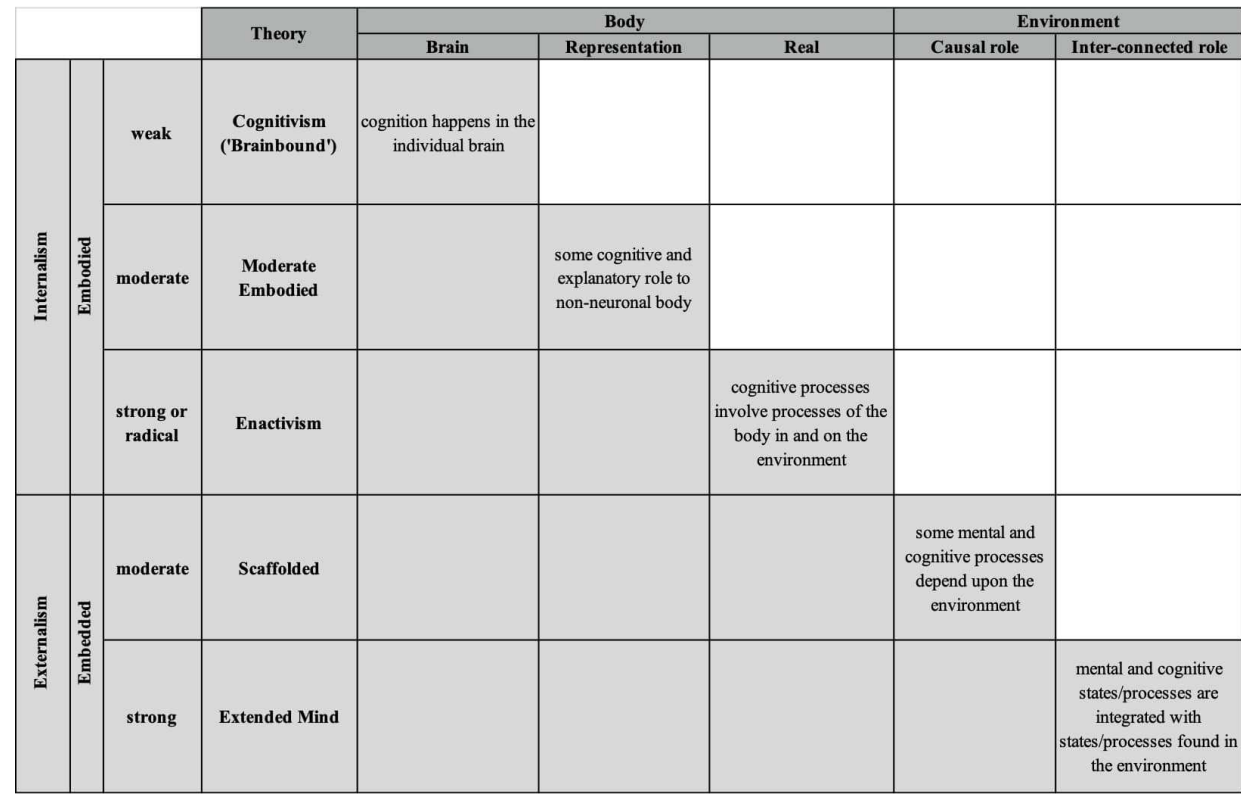

Table 1 - Role of representations, physical body and environment according to different views about human cognition (adapted from Menary 2010b, Airoldi 2019, Newen et al. 2018).

\section{WHAT WE TALK ABOUT WHEN WE TALK ABOUT EVOLUTION}

Darwin's theory of natural selection aims at providing a common explanation to the questions of where evolutionary novelties come from and why organisms are so well adapted to the environment. While few question selective accounts of adaptation, the debate in evolutionary biology increasingly focuses on whether selection is a necessary and sufficient condition for the appearance of novel phenotypic traits: the literature is immense and growing (for a brief anthology, Airoldi 2018). In this section, we criticise the adaptationist paradigm and introduce some of the non-adaptationist explanations for evolutionary novelty that seem more relevant to the issue of cognition.

\section{The metaphysics behind the adaptationist paradigm}

Adaptationism interprets most traits of organisms as adaptations, evolved thanks to the long and slow process of natural selection acting on casual, small and fitness-increasing variations continuously arising in each generation (Lewontin 1984): it is "the myth that all of evolution can be explained by adaptation" (Lynch 2007: 8597). The external environment defines relevant functions, and functions 
shape the phenotype through selective optimization: we will show how this externalist and functionalist flavour greatly limits adaptationism's explicative power.

\section{The reification of the concept of niche}

Niche is considered an objective entity with intrinsic properties, independent of the species living in and adapted to it. "The enormous diversity of organisms may be envisaged as correlated to the immense variety of environments and ecological niches which exists on earth" (Dobzhansky 1958: 9). So, species are, like Heidegger's Dasein, 'thrown into' a previously existing and independent environment, where they have to find their way of surviving. But niches (and the evolutionary problems they impose) are identified ex-post by reference to the organisms they host: that the creature's phenotypes are extremely well fit to live in them is a tautology, as "whether a feature of the environment constitutes an evolutionary problem for a creature depends on whether the creature's phenotype was selected for solving it (Fodor \& Piattelli-Palmarini 2010: 140) and, if the fit between niche and organism is not 'perfect', "all that follows is that that isn't exactly the niche that the species occupies" (147). Far from being an objective entity, ecological niches in adaptationism turn out to be intensional objects (144).

\section{The functionalization of the phenotype}

The phenotype is seen as a set of traits, each optimized to perform a function that contributes to the global fitness of the organism in the specified environment. Organisms are modular computing machines programmed to find the best solution to the problem of survival:

The diversity of animals known to have stereo vision [...] prompts the question of whether all animals have evolved essentially the same algorithms to implement stereopsis. (Nityananda \& Read 2017: 2502, emphasis added)

Two consequences are entailed by this view. On the one hand, function always precedes and justifies form:

Form is arbitrary (subject to functional adequacy) and the cause of the existence of a feature is its functional significance. (Linde-Medina 2011: 582, emphasis added)

On the other hand, the phenotype is decomposable in independently selected traits, given that "a linear combination of the characters which have no genetic correlations" can always be found (Lande 1976: 317). The problem is that traits never appear isolated (Figure 1), and fragmentation of an organism is, again, an observer-dependent task: "the process by which traits are distinguished from one another is a human measurement process" (Altenberg 2005: 100) that ignores many of the organism irreducible systemic features. 

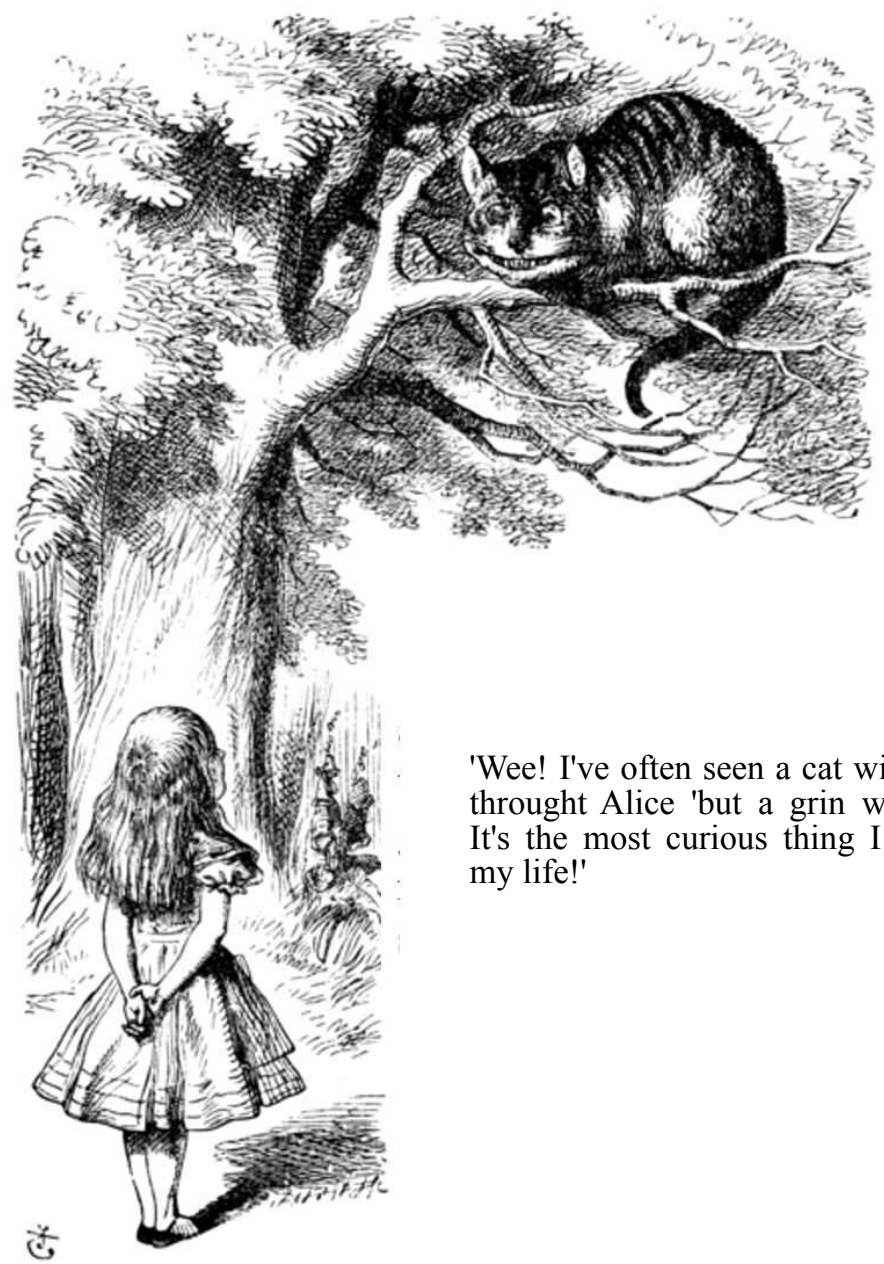

'Wee! I've often seen a cat without a grin,' throught Alice 'but a grin without a cat! It's the most curious thing I ever saw in my life!'

Figure 1: Alice and the Cheshire cat: individuation of a trait (the grin) without the individual (the cat) is a curious thing indeed! (image from Alice's Adventures in Wonderland by Lewis Carroll, illustrated by John Tenniel. London: Macmillan and Co, 1865)

\section{The optimization action of selection}

Selection is a creative and fitness optimization process. Acting at all time and upon all traits, selection is the deus-ex-machina able to solve the most intricate problems so efficiently that it should inspire human engineers:

[the algorithm supporting stereo vision] must be the best way to do stereo vision, and should be implemented by engineers in machine stereopsis. (Nityananda \& Read 2017: 2502, emphasis added)

Adaptationism becomes "permeated with dogmatic statements" and "adherence to the adaptationist paradigm" is religious (Lynch 2007: 8598-8599): in its extreme 
versions, it takes a theological flavour (Figure 2).

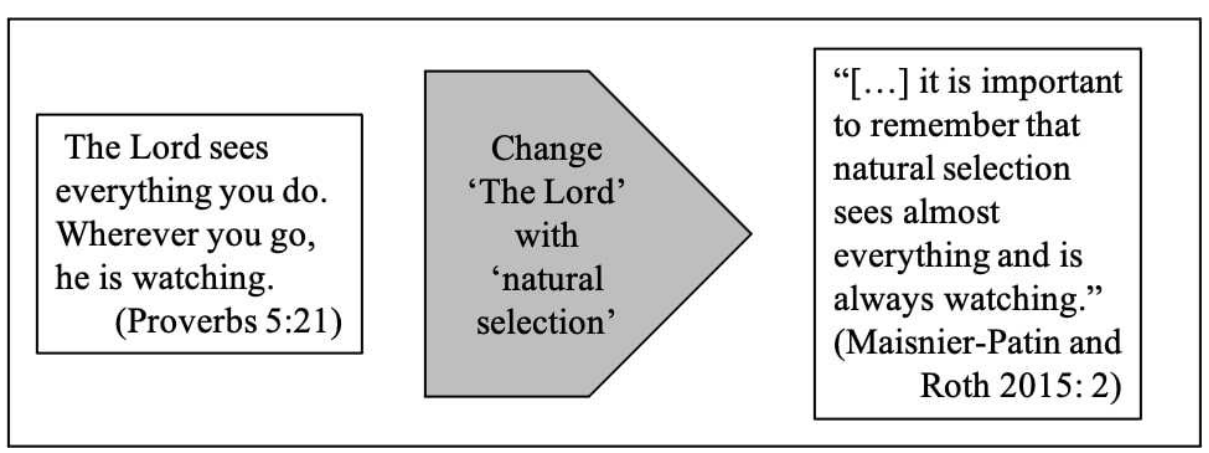

Figure 2: The theological aspect of selection in extreme adaptationist views.

Arguments in favour of the optimization power of selection usually rest on Fisher's Fundamental Theorem of Natural Selection (1930), an equation that forecasts the increase in the frequencies of genes positively correlated with individual fitness: but Fisher never talks about optimization. Actually, fitness can increase under selection only if environmental conditions, including other genes' effects, remain constant: a barely realistic scenario. Genetic and mating systems usually introduce constraints that prevent fitness maximisation. Recent simulation in evolutionary computation shows that evolution is better explained abandoning fitness maximization and just looking for novel behaviour (Lehman and Stanley 2011).

Given that selection acts on small and incremental variations, its optimizing action also entails a kind of 'trial-and-error' creative power: Fisher claims it is "a mechanism for generating an exceedingly high degree of improbability" (Huxley 1953). The issue is controversial: denial of any creative power of selection has a long tradition (for a review, see Razeto-Barry and Frick 2011). For Neander (1995), an organism exists because of the line of its ancestors, regardless of which other organisms existed besides; a world with unlimited resources would be populated by all kind of creatures, included the ones eliminated by selection in ours; therefore, selection cannot be the source of novelties: "much of the order we see in organisms may be the direct result not of natural selection but of the natural order selection was privileged to act on" (Kauffman 1993: 173, emphasis added). Selection just explains 'what is successful among the possible', not 'what is possible among the conceivable' (Rasskin-Gutman and Esteve-Altava 2009): this is the real mystery of evolution (Moczek 2008, Lynch 2007, Wagner 2015).

\section{Pluralistic proposals or evolution beyond selection}

Criticisms to adaptationism are widespread, and propose sources of variation other than random mutation and recombination, suggesting that novelties already come with some intrinsic degree of complexity. The Extended Evolutionary Synthesis (EES), for example, aims at including in evolutionary explanations some non-selective mechanisms, processes and constraints that might affect the origin of variation (Laland et al. 2015). Non-adaptationist accounts are sometimes collected under the umbrella concept of 
'pluralism', conveying the idea that evolution is caused, together with natural selection, by other laws and processes, as well as by historical contingencies (Gould 1997). In this section, we mention some of these accounts that we think might have been relevant for the evolution of cognition, and we classify them based on where novelties are supposed to come from: genotype, phenotype, developmental system, and the complex system constituted by them and the ecological niche.

\section{Genetic accounts}

The complexity of the genes' expression and mutual relationships and their molecular richness dismounts the simplistic account of the phenotype as deterministic and linear output of the genotype, so that small mutations become small selectable phenotypic changes. Mechanisms other than random mutations and recombination must be considered. Wright's 'shifting balance' theory (1982) points at the creative potential of new mixes of existing alleles that are not allowed under selection alone, but possible thanks to casual genetic drift. Kimura (1983: xi) proposes his neutral theory as an alternative to adaptationism at the level of molecular evolution. Form anticipates function at the genomic level, according to Wagner (2015), whose investigations reveal how the underlying structures of genetic and metabolic networks allow the 'sudden' appearance of novel functions: novelties can occur without macro-mutations, thanks to the subjacent architecture of the chemistry of life.

\section{Phenotypic accounts}

Some proposals look for variations at the phenotypic level, where selection takes place. Thompson (1942) claims that physical laws, and not heredity and selection, mould the forms of life. Gould and Lewontin (1979) introduce the concept of exaptation, or phenotypic structures that contributes to the feasibility of an organism without being built by selection for their current role (e.g. exaptation of bones, initially selected to store calcium, as structural elements): function can be parasitic on form, and form can be just a by-product of pre-existing structures. Neo-Lamarckian proposals suggest that what is learnt in one generation impact the genetic pool of the following (the 'Baldwin effect'), that the usefulness of a non-genetic trait can be genetically encoded through 'genetic assimilation' and that environmental stress can induce mutations in specific genes, able to provide adaptive responses (Jablonka and Lamb 2005).

\section{Developmental accounts}

Genetic information alone is not enough to create a phenotype. The plasticity of developmental systems can foster quick evolutionary changes: developmental paths can suffer modifications and these modifications can be inherited without being coded in the genotype (Abzhanov et al. 2004); Evolutionary-Developmental (Evo-Devo) research focuses on how developmental bias configure phenotypes and their potential evolution (Müller 2008).

\section{Systemic accounts}


Adaptationism interprets complexity as a result, and not a target, of selection. Systemic accounts see things the other way round: complexity can appear spontaneously as a consequence of physical, chemical and thermodynamic laws, as well as of universal principles governing complex systems, and only afterwards be submitted to the judgement of selection. Complex forms can be the result of simple natural laws, like the cell's membrane (Newman et al. 2006). Thermodynamic processes can propel the rise of complex order locally, while increasing entropy at a global level (Brooks and Wiley 1986). Complex systems composed by elements interacting in multiple, non-linear ways can selforganise: selection just picks up the most evolvable among such spontaneously generated systems (Kauffman 1993). According to the proposal of 'evolution as natural drift' (Varela et al. 2016), selection underdetermines phenotypic traits: evolution is not a question of optimization, of survival of the fittest, but rather of viability, of non-survival of the notenough fit. Traits appear not as adaptations but thanks to some peculiar conditions specifically fulfilled by living systems: the richness of the self-organizing capacities in biological networks, a mode of structural coupling permitting the satisficing of viable trajectories, and the modularity of subnetworks of independent processes that interact with each other. Organisms pass on to the next generation genes as well as an environment in which these genes are embedded: the genome is ecologically embedded.

Figure 3 summarizes the two views. According to adaptationism, variations come from random mutations and recombinations, the genotype univocally determines the phenotype, while developmental and systemic interactions are ignored, and the final source of form and function is always the ecological niche. Pluralistic accounts claim that developmental processes and the phenotype play an active part in the explanation of evolutionary change, and that the phenomena that trigger such changes encompass much more than just mutation and recombination: adaptive and non-adaptive traits coexist.

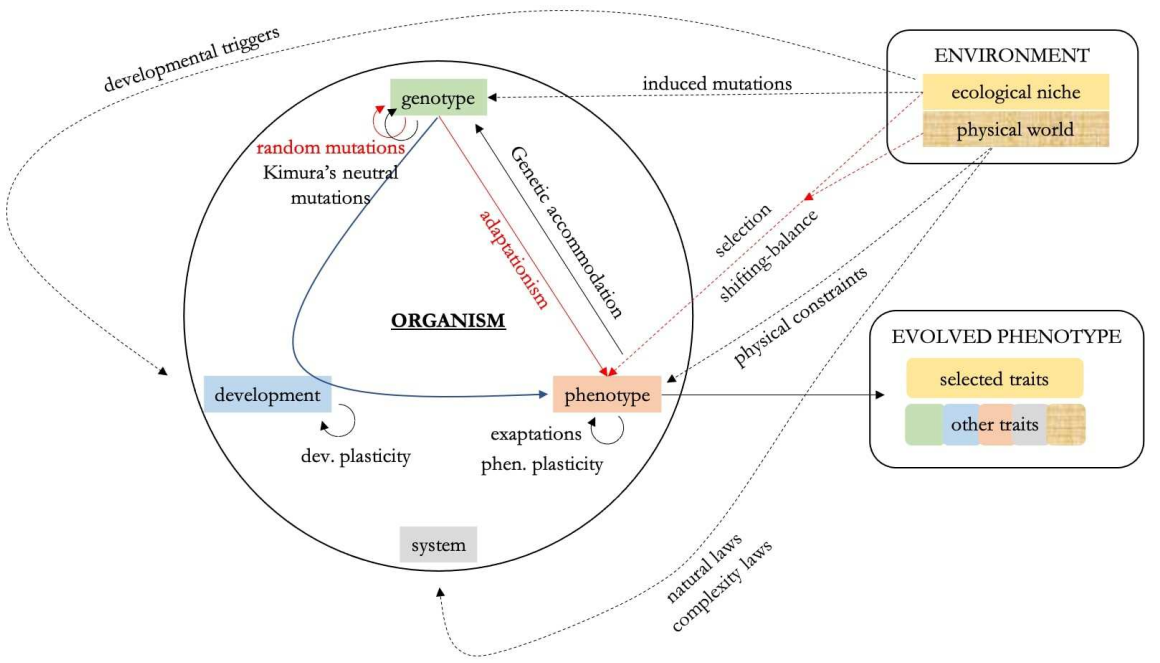

Figure 3: The logical blocks of the organism and their role in evolution according to the adaptationist view (red lines) and under a pluralistic approach of evolution (black lines). Colours in the evolved phenotype box show possible sources of novelties. 


\section{WHERE DID THE SMARTEST COME FROM?}

How cognition appeared and evolved are topics with a long and tormented history: the Paris Linguistic Society foundational statute of 1866 prohibited studies around the evolution of language, for being 'a-scientific' (Yamauchi et al. 2012). Darwin's theory supplied a scientific paradigm to the hypothesis of cognitive evolution: it was just a question of finding the right selective pressure. The issue was now fuelling the theory with reliable evidence, a twofold problem: cognition itself is a polysemic concept, as it possibly includes

[...] odor and taste discrimination, number ability, word fluency, spatial ability, memory, timing of language acquisition, spelling, sentence construction, perceptual skill. (Lumsden and Wilson 1981: 16)

So it is not evident what the subject of our quest should be; and direct fossil and archaeological records of cognition are impossible, as number and spatial ability, memory and the like tend not to leave direct fossil evidence. Nonetheless, the literature is full of adaptive accounts of the evolution of cognitive abilities, although our knowledge does not seem to have improved at present, as Lewontin underlines:

If $[\ldots]$ it were our purpose in this chapter to say what is actually known about the evolution of human cognition, we could stop at the end of this sentence. (Lewontin 1990: 22)

In this section, we first discuss what evidence is usually looked for to support the hypothesis on the evolution of cognition. We then list some of the adaptive hypotheses founded on those evidences. We finally mention some examples of nonadaptationist accounts.

\section{What do we look for when we look for evidence of cognition?}

If defining cognition is an issue, deciding what counts as evidence of cognition is another. Abilities are intangible and their direct fossil evidence is extremely hard to find, so gathering data on the evolution of cognition is an intensively theory-laden task: we must first decide what the sign of the cognitive is (its function), and where (at least in part) it takes place (its form), before we look for its historical clues.

Cognitive abilities' form has been typically identified in a species' average brain size (Roth and Dicke 2005, Dunbar and Shultz 2007), proxy for more subtle and fundamental characteristics of the brain such as the total number of neurons and glial cells or the complexity of the neural interconnections (Jeirson 1973). More specifically, the ratio of brain to body size (the index of cephalization) is deemed to represent the amount of brain tissue in excess of that required for transmitting impulses to and from the integrative centers (Lashley, 1949). The evolution of this ratio is interpreted as reflecting the relative changes in the selective forces acting on the brain and body (Lande 1979). Comparative biology looks for relationships between brain size and other characters of a species that could testify of some specific cognitive ability. A classical hypothesis links brain size and cognition, but the brain-cognition equivalence is questioned by species with tiny brains and remarkable behaviours (e.g. flexible hunting tactics of salticid spiders, Tarsitano and Jackson 1994). Moreover, there is little consensus around the mapping of cognitive capacities onto brain structure (Sperber 1994, Healy and Rowe 2007), although agreement exists that cerebral lateralization is somehow linked to the rise of linguistic abilities (Gazzaniga 1983), usually considered a 
sign of the cognitive (Deacon 1997, Pinker \& Bloom 1992). Lateralization is reflected in the fossil record by evidence of the preponderant use of the right hand, inferred for example through signs left on shards from stone tools manufacturing.

Other indirect evidence of cognitive abilities are anatomical modifications correlated with the use of tools, such as changes in bones' densities (Eckhardt 2000) or in hands and musculature to accommodate the grips required for manufacturing tools (Marzke 1997).

Instead of looking for fossil records of the form of cognition, other strategies focus directly on archaeological evidence of the functions of cognition. Evidence of environmental manipulation (remains of fires and cooking, tools, etc.) are often used as proxies of cognitive functions, as they are considered "pieces of the cognitive machinery of our hominin ancestors" (Jeffares 2010). Of course, their interpretation requires additional hypotheses (usually supplied by Evolutionary Psychology) on which abilities they are evidence of: a 'black box' remains between environmental inputs and behaviours (Jeffares 2010). This 'reverse engineering' goes from putative evidence of behaviours to hypotheses around the cognitive abilities required for these behaviours. Tools, for example, can be manufactured when needed, or created in advance and stored for future uses; they can be a signalling of status (late mode 2 Acheulean tools often show baroque features and seem unused) ${ }^{1}$ or of the bearer's role in the group, etc. Each of these behaviours require different cognitive abilities: maintaining mental templates, distributing attention among several tasks, having a goal in mind.

\section{Cognition by selection}

No doubt, the majority of evolutionary explanations around cognition are adaptationist, under the unquestioned view that "intelligence must have evolved under the influence of natural selection." (Jerison 1973: 5, emphasis added). The first words in Geary's Origin of Mind (2004: 3) are: "Charles Darwin and Alfred Wallace independently discovered the mechanism of natural selection". This does not come as a surprise, if we consider that most hypotheses around the human mind are representational in nature (e.g. "I regard the mind and conscious experience as constructions of nervous systems to handle the overwhelming amount of information that they process" Jerison 1973: 4, emphasis added) and that representationalcognitivist theories and adaptationism have a similar logical structure founded upon functionalism, externalism and optimality (Varela et al. 2016). Hominid evolution is represented by a continuous series of species with increasing cognitive abilities, evolved as a response to challenging environments. Human knowledge and language would thus be grounded on the simpler cognitive forms of our ancestors and closest relatives. Edelman's 'neural Darwinism' (1987) defends that the theory of natural selection can explain complex adaptation in brains, and so does Changeux (1983). Fernando et al. (2012) lists a long series of such cognitive-Darwinian approaches.

Brain size evolution has been linked to ecological problem-solving tasks such as diet or foraging strategies (Clutton-Brock and Harvey 1980). Dunbar (2001) builds an optimization model to demonstrate that neocortex relative size covaries with group size in hominid evolution, pushed by increasing cognitive requirements. Similar ideas support the 'social intelligence hypothesis' (Humphrey 1976), or the view that primate intelligence is an adaptation to complex social environments.

Evolutionary psychology describes evolution as the progressive improvement of a modular, problem-solving machine selected to cope with the environmental and social 
challenges of the Pleistocene:

[t] he architecture of the human mind acquired its functional organization through the evolutionary process (Cosmides Tooby 1994: 41, emphasis added)

The human brain/mind is an integrated bundle of complex mechanisms (adaptations). Each mechanism was designed by natural selection in past environments to promote the survival of the genes that directed its construction by serving some specific function (Symons 1992: 138, emphasis added)

Accounts concerning the evolution of language follow the same paradigm: selection is the most plausible mechanism behind its appearance (Lumsden and Wilson 1981), or the only possible one (Pinker and Bloom 1992). Sterelny claims that "[t]here is no serious doubt that the human mind is specifically adapted for the use of language" (2010: 328). There is an extended literature around which selective force fostered language (Cela Conde and Ayala 2001). Hewes (1973) claims that the neural connections needed for the production of stone tools and for gestural communications are similar, as both imply precise hands control: the need to use hands for two tasks at the same time - manufacturing tools and communicating - was the selective pressure to transform gestural into linguistic communication. Other authors identify this selective force in the problems of coordination during group foraging in $H$. erectus (Parker 1985), or in the mother-child relationship (Jonas and Jonas 1975).

All these assumptions rest on at least two adaptationist pillars. On the one hand, cognitive evolution entails appearance and selection of new behaviours and abilities linked to new phenotypic traits, thus to speciation events revealed by discontinuities in the fossil and archaeological records (Sterelny 2003: 353). Nevertheless, more refined tools do not entail evolution of their makers: the refined Arabic numerals co-existed with the Roman, and the users of both belonged to the same species; H. sapiens domesticated fire 100,000 years after its appearance (Lewontin 1990). On the other hand, these accounts detach the mind form the environment: the latter shapes the former through the selection of cognitive traits which enable fitness-increasing behaviour and culture - the cognitive function comes first and the visible cultural product comes after (Jeffares 2010).

In the 'niche construction' framework, Sterelny $(2003,2007,2010)$ faces both issues. He rejects the functionalist view and underlines the role played by the interconnections between cognition, behaviours and the socio-cultural world. Human cognitive evolution happens in selective environments created by earlier hominids, where the epistemic and informational environment is inherited as much as the genetic pool: the world shapes our cognition as much as our cognition shapes the world. Niche construction is a collective, epigenetic phenomenon that can explain why many cognitive capacities of $H$. sapiens (improved stone-making, novel tools and materials, trade, art) appeared abruptly in the Upper Palaeolithic Transition (50,000 to 40,000 years ago), disappeared sometime after and reappeared in different places and times: presumably this is because these abilities emerged from the dynamics of social groups interacting as complex systems, and not from speciation events.

We conclude this section with Sterelny's niche construction framework because it lies at the border of adaptationism, but is not yet non-selective. He criticises the 'extended phenotype' theory (Dawkins 1982), which has some points in common with his proposal, for its adaptationist view. Dawkins believes that species often permanently modify their environment (e.g. birds' nests) and that selection acts on the whole 'organism + modifications', or the 'extended phenotype'. The basis of the phenotype's 
'extended traits', though, lie in the genetics of the individual, which is the subject of selection. The extended phenotype kind of 'scaffolding' is passive and it cannot explain the evolution of extended cognition, while niche construction can. However, Sterelny's niche construction still relies on the optimization paradigm: hawks choose roosts to maximise the view of their hunting territory, and cognitive abilities spread thanks to their contribution to fitness.

\section{Non-selective accounts of evolution of cognition}

Adaptationist accounts of evolution should demonstrate the actual occurrence of the elements allowing selection: that there were differences in cognitive abilities among our remote ancestors, that these differences were heritable, and that they ensured a fitness advantage. Without such evidence, "[t]here is no end to plausible storytelling" (Lewontin 1990: 129). Note that these differences and their fitness advantages should exist among individuals of the species, and not between species: we might have evidence that a species with linguistic abilities replaced another without them, but this still does not explain how the abilities arose in the first place!

Non-selective hypotheses avoid this critical issue because they often offer mechanistic and not historical accounts. For example, neocortex evolution is justified either as an epiphenomenon, a by-product of the evolution of the body (Finlay \& Darlington 1995), or as a consequence of developmental, maternal metabolic input (Hofman 1983). These proposals, however, focus on brain as form, without considering how this form can result in brain functions, as it has been critically noticed (Dunbar 1998). The 'skin-brain thesis' (Keijzer et al. 2013) claims that nervous systems appeared to support muscular coordination and not intelligent behaviour, a later exaptation. Vrba (1995) suggests that brain size increase is a side-effect of body size increase pushed by climatic changes during hominid evolution. The brain is thus not the result of selective pressures and its associated cognitive faculties emerges from developmental experiences. The idea that complex structures can rest on physical laws is behind Cherniak's idea of 'non-genomic nativism' in brain structure (Cherniak 2009). Applying network optimization theory, he claims that the structure of nervous systems is based on the minimization of connection costs among parts, as it appears in the analysis of the macaque visual cortex. This 'pre-formatting' hypothesis postulates "innate abstract internal structure - as opposed to an empty-organism blank-slate account" (2009: 115): a structure that allows self-organization of macaque's brain structured according to logistic path optimization.

A growing number of authors disagree with the selective account of the evolution of language. Chomsky (1980) denies that selection can explain the origin of such a complex and sophisticated trait, whose potentialities largely exceed biological utility. Language would be a by-product, due to pleiotropy (or the effect of a gene upon multiple phenotypic traits) of genes involved in the selective process of encephalization, but not submitted itself to selection. Gould interprets likewise language as an exaptation (Gould 1987). Dor and Jablonka (2000) suggest that behaviour can be genetically assimilable thanks to individual plasticity: so, language did not evolve through the accumulation of casual beneficial mutations, but has appeared thanks to the continuous interactions between individuals within a cultural niche, and has afterwards been encoded through genetic assimilation (such as the Baldwin effect) made possible by individual plasticity. Piattelli-Palmarini and Uriagereka (2008) propose that different evolutionary mechanisms might be involved in 
the evolution of different aspects of language. Among these mechanisms, PiattelliPalmarini (1989) suggests that language might have appeared as an exaptation and that Fibonacci's growth patterns are to be found in the structure of human language, pointing at an interpretation of language as an emerging physical property of the brain as a complex dynamical system (Piattelli-Palmarini and Uriagereka 2008).

Psychologists, philosophers and the cognitive scientists in general are proposing new ways in which cognitive capacities are shaped by the developmental process. Jacobs and Jordan (1992) believe that the brain has a functional and modular structure that reflects the modular structure present in the environment. Although their view is clearly computational/representational, instead of founding it on a selective hypothesis, they claim that "certain aspects of the modular organization of the adult brain arise developmentally" and that "the system [modelling the brain] develops characteristics that are typically associated with topographic maps" (Jacobs and Jordan 1992: 323, emphasis added). Stotz (2010) criticises the niche construction paradigm in favour of developmental niche construction, underlining the importance of developmental factors in shaping the cognition of individuals.

The proposal by Varela et al. (2016) is possibly the most explicit antiadaptationist view of the evolution of cognition. Similar to niche construction in the view of cognition as embodied action, it detaches itself from Sterelny's view by suggesting that natural drift, and not adaptation, explains evolution. Against the 'cognition-as-representation/evolution-as-adaptation' joint paradigm, the authors claim that cognition does not consist in problem-solving through manipulation of representations, but emerges from histories of structural coupling that are not optimal but simply viable, in which the environment is not a pre-given source of inputs, but an integral, enacted part of the evolutionary phenomenon.

Although still scarce compared to selective narratives, these examples show that non-adaptationist accounts concerning the evolution of cognition can better support the novel, non-representational theories of mind. Their pluralistic approach allows explanations based on the combined actions of different processes and forces, including of course selection, and their mechanistic nature frees them from the need to support the respective hypotheses on palaeontological and archaeological evidence.

\section{CONCLuSIONS}

The turn of the millennium has brought novel and fecund theories in the areas of both evolutionary biology and of philosophy of mind. In the first case, the preponderant role of selection in evolution has been challenged, and alternative mechanisms have been proposed as sources of novelties. In the second case, the representational theories of mind have been likewise criticised for being unable to explain all aspects of human cognition, that is often inter-dependent on active external resources. The extension of classical theories in both areas better captures the complex and interwoven realities of life and mind.

Nonetheless, there seems to have been little communication between these two disciplinary worlds: most evolutionary accounts in the philosophy of mind still follow the adaptationist paradigm, while the cognitivist-representational paradigm still reigns in evolutionary biology. We have started to suspect that intelligence is not just efficient problem-solving, and that evolution is not just, in Darwin's word, war of nature, famine and death: we should now merge our investigations about 'who the smartest is' and 'where the smartest arrived from' into a unified approach. The task is no doubt titanic: 
the potential it offers, we believe, unlimited.

\section{REFERENCES}

ABZHANOV, A.; PROTAS, M.; GRANT, B. R.; GRANT, P. R.; TABIN, C. J. Bmp4 and morphological variation of beaks in Darwin's finches. Science, v. 305, n. 5689, p. 1462-1465, 2004.

ADAMS, F.; AIZAWA, K. The bounds of cognition. Philosophical Psychology, v. 14, n. 1, p. 43-64, 2001.

ADAMS, F.; AIZAWA, K. (2010), Defending the bound of cognition. In: MENARY, R. (Ed.) The extended mind. Cambridge, MA: The MIT Press, 2010. p. 67-80.

AIROLDI, G. More than fitness: a robustness-based proposal of a logical space to classify processes behind evolutionary phenomena. Kairos: Journal of Philosophy \& Science, v. 20, n. 1, p. 89$112,2018$.

AIROLDI, G. The extended mind hypothesis: an anti-metaphysical vaccine. Revista Sofia, v. 8, n. 1, p. 10-29, 2019.

ALTENBERG, L. Modularity in evolution: some low-level questions. In: CALLEBAUT, W.; RASSKIN-GUTMAN, D.; SIMON, H. (Eds.) Modularity: understanding the development and evolution of natural complex systems. Cambridge, MA: The MIT Press, 2005. p. 99-128.

BECHTEL, W. Philosophy of mind: an overview for cognitive science. New York, London: Psychology Press, 1988.

BROOKS, R. A. Intelligence without representation. Artificial Intelligence, v. 47, n. 1-3, p. 139-159, 1991.

BROOKS, R. A. Cambrian intelligence: the early history of the new AI. Cambridge, MA: The MIT Press, 1999.

BROOKS, D. R.; WILEY, E. O. Evolution as entropy. Chicago: The University of Chicago Press, 1986.

CARROLL, L. Alice's adventures in wonderland. Illustrated by John Tenniel. London: Macmillan and Co., 1865.

CELA CONDE, C. J.; AYALA, F. J. Senderos de la evolución humana. Madrid: Alianza Editorial, 2001.

CHANG, F. Symbolically speaking: a connectionist model of sentence production. Cognitive Science, v. 26, n. 5 , p. $609-651,2002$.

CHANGEUX, J. P. L'Homme neuronal. Paris: Fayard, 1983.

CHEMERO, A. Radical embodied cognitive science. Cambridge, MA: The MIT Press, 2009.

CHERNIAK, C. Brain wiring optimization and non-genomic nativism. In: PIATTELLI-PALMARINI, M.; URIAGEREKA, J.; SALUBURU, P. (Eds.) Of minds and language: a dialogue with Noam Chomsky in the Basque Country. Oxford: Oxford University Press, 2009. p. 108-119.

CHOMSKY, N. Language and problems of knowledge: the Managua lectures. Cambridge, MA: The MIT Press, 1980.

CLARK, A. Re-inventing ourselves: the plasticity of embodiment, sensing, and mind. The Journal of Medicine and Philosophy, v. 32, n. 3, p. 263-282, 2007.

CLARK, A. Memento's revenge: the extended mind extended. In: In: MENARY, R. (Ed.) The extended mind. Cambridge, MA: The MIT Press, 2010. p. 43-66.

CLARK, A. Supersizing the mind: embodiment, action, and cognitive extension. Oxford: Oxford University Press, 2011.

CLARK, A.; CHALMERS, D. J. The extended mind. Analysis, v. 58, n. 1, p. 07-19, 1998.

CLUTTON-BROCK, T. H.; HARVEY, P. H. Primates, brains and ecology. Journal of Zoology, v. 190, p. 309-323, 1980.

COSMIDES, L.; TOOBY, J. Beyond intuition and instinct blindness: towards an evolutionarily rigorous cognitive science. Cognition, v. 50, p. 41-77, 1994.

COWAN, W. M.; FAWCETT, J. W.; O'LEARY, D. D.; STANFIELD, B. B. Regressive events in neurogenesis. Science, v. 21, p. 1258-1265, 1984.

DAWKINS, R. The extended phenotype. Oxford: Oxford University Press, 1982.

DEACON, T. W. The symbolic species: the co-evolution of language and the brain. New York; London: W. W. Norton \& Co., 1997.

DOBZHANSKY, T. Genetics and the origin of species. 3.ed. New York: Columbia University Press, 1958.

DOR, D.; JABLONKA, E. From cultural selection to genetic selection: a framework for the evolution of language. Selection, v. 1, n. 1-3, p. 33-55, 2000. 
DUNBAR, R. I. Brains on two legs: group size and the evolution of intelligence. In: WAAL, F. (Ed.) Tree of origin. Cambridge, MA: Harvard University Press, 2001. p. 173-92.

DUNBAR, R. I., SHULTZ, S. Understanding primate brain evolution. Philosophical Transactions of The Royal Society B: Biological Sciences, v. 362, n. 1480, p. 649-58, 2007.

EDELMAN, G. Neural darwinism: the theory of neuronal group selection. New York: Basic Books, 1987.

26 FERNANDO, C.; SZATHMARY, E.; HUSBANDS, P. Selectionist and evolutionary approaches to brain function: a critical appraisal. Frontiers in Computational Neuroscience, v. 6, Article 24, p. 01-28, 2013.

FINLAY, B.; DARLINGTON, R. Linked regularities in the development and evolution of mammalian brains. Science, v. 268, p. 1678-1684, 1995.

FISHER, R. A. The genetical theory of natural selection. Oxford: Clarendon Press, 1930.

FODOR, J.; PIATTELLI-PALMARINI, M. What Darwin got wrong. London: Profile Books, 2010.

GALLAGHER, S. How the body shapes the mind. Oxford: Oxford University Press, 2005.

GAZZANIGA, M. S. Right hemisphere language following brain bisection: a 20 -year perspective. American Psychologist, v. 38, n. 5, p. 525-537, 1983.

GEARY, D. C. The origin of mind: evolution of brain, cognition, and general intelligence. New York: American Psychological Association, 2004.

GOULD, S. J. The limits of adaptation: is language a spandrel of the human brain? Paper presented to the Cognitive Science Seminar, Center for Cognitive Science. Cambridge, MA: MIT, 1987.

GOULD, S. J. Evolution: the pleasures of pluralism. The New York Review of Books, v. 44, p. 47-52, 1997.

GOULD S. J.; LEWONTIN, S. The spandrels of San Marco and the Panglossian paradigm: a critique of the adaptationist program. Proceedings of the Royal Society B, v. 205, p. 581-598, 1979.

GRAVES, A., WAYNE, G., DANIHELKA, I. Neural Turing Machines. arXiv:1410.5401, p. 01-26, 2014.

GREVE, R. B.; JACOBSEN, E. J.; RISI, S. Evolving neural Turing machines for reward-based learning. Proceedings of the Genetic and Evolutionary Computation Conference, p. 117-124, 2016.

HEALY, S.; ROWE, C. A critique of comparative studies of brain size. Proceedings of the Royal Society B: Biological Sciences, v. 274, n. 1609, p. 453-64, 2007.

HEWES, G. W. An explicit formulation of the relation between tool-using and early human language emergence. Visible Language, v. 7, p. 102-127, 1973.

HOFMAN, M. A. Evolution of the brain in neonatal and adult placental mammals: a theoretical approach. Journal of Theoretical Biology, v. 105, p. 317-322, 1983.

HUMPHREY, N. K. The social function of intellect. In: BATESON, P.; HINDE, R. (Eds.) Growing points in ethology. Cambridge: Cambridge University Press, 1976. p. 303-317.

HUTTO, D.; MYIN, E. Radicalizing enactivism: basic minds without content. Cambridge, MA: The MIT Press, 2012.

HUXLEY, J. Evolution in action. London: Chatto and Windus, 1953.

JACOBS, R. A.; JORDAN, M. I. Computational consequences of a bias toward short connections. Journal of Cognitive Neuroscience, v. 4, n. 4, p. 323-336, 1992.

JABLONKA, E.; LAMB, M. J. Evolution in four dimensions: genetic, epigenetic, behavioral, and symbolic variation in the history of life. Cambridge, MA: The MIT Press, 2005.

JEFFARES, B. The co-evolution of tools and minds: cognition and material culture in the hominin lineage. Phenomenology and the Cognitive Sciences, v. 9, p. 503-520, 2010.

JERISON, H. J. Evolution of the brain and intelligence. New York; London: Academic Press, 1973.

JONAS, D. F.; JONAS, A. D. Gender differences in mental function: a clue to the origin of language. Current Anthropology, v. 16, 626-630, 1975.

KAUFFMAN, S. A. The origins of order: self-organization and selection in evolution. Oxford: Oxford University Press, 1993.

KIMURA, M. The neutral theory of molecular evolution. Cambridge: Cambridge University Press, 1983.

KEIJZER, F.; VAN DUIJN, M.; LYON, P. What nervous systems do: early evolution, input-output, and the skin brain thesis. Adaptive Behavior, v. 21, n. 2, p. 67-85, 2013.

LALAND, K. N.; ULLER, T.; FELDMAN, M. W.; STERELNY, K.; MULLER, G. B.; MOCZEK, A.; JABLONKA, E.; ODLING-SMEE, J. The extended evolutionary synthesis: its structure, assumptions and predictions. Proceedings of the Royal Society B, v. 282, Article 20151019, p. 01-14, 2015.

LANDE, R. Natural selection and random genetic drift in phenotypic evolution. Evolution, v. 30, p. 314-334, 1976. 
LANDE, R. Quantitative genetic analysis of multivariate evolution, applied to brain:body size allometry. Evolution, v. 33, n. 1, p. 402-416, 1979.

LASHLEY, K. S. Persistent problems in the evolution of mind. Quarterly Review of Biology, v. 24, p. 28-42, 1949.

LEHMAN, J.; STANLEY, K. O. Abandoning objectives: Evolution through the search for novelty alone. Evolutionary Computation, v. 19, n. 2, p. 189-223, 2011.

LEWONTIN, R. C. Adaptation. In: SOBER, E. (Ed.) Conceptual issues in evolutionary biology. Cambridge, MA: The MIT Press, 1984. p. 235-251.

LEWONTIN, R. C. The evolution of cognition. In: OSHERSON, D. N.; SMITH, E. (Eds.) Thinking: an invitation to cognitive science, Vol. 3. Cambridge, MA: The MIT Press, 1990. p. 229-246.

LINDE-MEDINA, M. Adaptation or exaptation? The case of the human hand. Journal of Biosciences, v. 36, n. 4, p. 575-585, 2011.

LUMSDEN, C. J., WILSON, E. O. Genes, minds, and culture. Cambridge, MA: Harvard university Press, 1981.

LYNCH, M. The frailty of adaptive hypothesis for the origins of organismal complexity. Proceedings of the National Academy of Sciences of the United States of America, v. 104, n. 1 p. 8597-8604, 2007.

LYON, P. The biogenic approach to cognition. Cognitive Processing, v. 7, p. 11-29, 2006.

MAISNIER-PATIN, S.; ROTH, J. R. The origin of mutants under selection: how natural selection mimics mutagenesis (adaptive mutation). Cold Spring Harbor Perspectives in Biology, v. 7, n. 7, a018176, 2015.

MARZKE, M.W. Precision grips, hand morphology, and tools. American Journal of Physical Anthropology, v, 102, p. 91-110, 1997.

MENARY, R. (Ed.) The extended mind. Cambridge, MA: The MIT Press, 2010. (2010a)

MENARY, R. Introduction to the special issue on 4E cognition. Phenomenology and the Cognitive Sciences, v. 9, p. 459-463, 2010. (2010b).

MOCZEK, A. P. On the origins of novelty in development and evolution. BioEssays, v. 30, n. 5, p. 432477, 2008.

MORGAN, T. H. Evolution and genetics. Princeton, NJ: Princeton University Press, 1925.

MULLER, G. B. Evo-Devo as a discipline. In: MINELLI, A.; FUSCO, G. (Eds.) Evolving pathways: key themes in evolutionary developmental biology. Cambridge: Cambridge University Press, 2008. p. 05-30.

NEANDER, K. Pruning the tree of life. The British Journal for the Philosophy of Science, v. 46, n. 1, p. 59-80, 1995.

NEISSER, U. Cognitive psychology. New York: Appleton-Century-Crofts, 1967.

NEWEN, A.; DE BRUIN, L.; GALLAGHER, S. (Eds.) The Oxford handbook of $4 E$ cognition. Oxford: Oxford University Press, 2008.

NEWNAM, S. A.; FORGACS, G.; MULLER, G. B. Before programs: the physical origination of multicellular forms. International Journal of Developmental Biology, v. 50, p. 289-299, 2006.

NITYAINANDA, V.; READ, J. C. A. Stereopsis in animals: evolution, function and mechanisms. The Journal of Experimental Biology, v. 220, n. 14, p. 2502-2512, 2017.

PARKER, S. T. A social-technological model for the evolution of language. Current Anthropology, v. 26, p. 617-639, 1985.

PIATTELLI-PALMARINI, M. Evolution, selection, and cognition: From "learning" to parameter setting in biology and the study of language. Cognition, v. 31, p. 01-44, 1989.

PIATTELLI-PALMARINI, M., URIAGEREKA, J. Still a bridge too far? Biolinguistic questions for grounding language on brains. Physics of Life Reviews, v. 5, p. 207-224, 2008.

PINKER, S.; BLOOM, P. Natural language and natural selection. In: BARKOW, J.; COSMIDES, L.; TOOBY, J. (Eds.) The adapted mind. Oxford: Oxford University Press, 1992.

RASSKIN-GUTNAN, D.; ESTEVE-ALTAVA, B. Modeling Evo-Devo: broken hierarchies and multiple scales of organization and complexity. AIP Conference Proceedings, v. 167, p. 43-56, 2009.

RAZETO-BARRY, P.; FRICK, R. Probabilistic causation and the explanatory role of natural selection. Studies in History and Philosophy of Biological and Biomedical Sciences, v. 42, n. 3, p. 344$355,2011$.

REEKE, G.; EDELMAN, G. M. Artificial Intelligence. Daedalus, v. 117, n. 1, p. 143-173, 1988.

ROTH, G.; DICKE, U. Evolution of the brain and intelligence. Trends in Cognitive Sciences, v. 9, n. 5, p. 250-257, 2005.

RUPERT, R. D. Challenges to the hypothesis of extended cognition. Journal of Philosophy, v. 101, n. 8, p. 389-428, 2004.

SMOLENSKY, P. Tensor product variable binding and the representation of symbolic structures in 
connectionist systems. Artificial Intelligence, v. 46, n. 1-2, p. 159-216, 1990.

SPERBER, D. The modularity of thought and the epidemiology of representations. In: HIRSCHFELD, L. A.; GELMAN, S. A. (Eds.) Mapping the mind: domain specificity in cognition and culture. Cambridge: Cambridge University Press, 1994. p. 39-67.

STERELNY, K. Thought in a hostile world: the evolution of human cognition. Malden: Blackwell, 2003.

28 STERELNY, K. Social intelligence, human intelligence and niche construction. Proceedings of the Royal Society B, v. 362, n. 1480, p. 719-730, 2007.

STERELNY, K. Minds: extended or scaffolded? Phenomenology and the Cognitive Sciences, v. 9, p. 465-481, 2010.

STERELNY, K Culture and the extended phenotype: cognition and material culture in deep time. In: NEWEN, A.; DE BRUIN, L.; GALLAGHER, S. (Eds.) The Oxford handbook of 4 E cognition. Oxford: Oxford University Press, 2008. p. 773-792.

STOTZ, K. Human nature and cognitive-developmental niche construction. Phenomenology and the Cognitive Sciences, v. 9, p. 483-501, 2010.

SUTTON, J. (2010). Exograms and Interdisciplinarity. In: MENARY, R. (Ed.) The extended mind. Cambridge, MA: The MIT Press, 2010. p. 189-225.

SYMONS, D. (1992). On the use and misuse of darwinism in the study of human behavior. In: BARKOW, J.; COSMIDES, L.; TOOBY, J. (Eds.) The adapted mind. Oxford: Oxford University Press, 1992. p. 137-162.

TARSITANO, M. S.; JACKSON, R. R. Jumping spiders make predatory detours requiring movement away from prey. Behaviour, v. 131, n. 1-2, p. 65-73, 1994.

THOMPSON, D. On growth and form. 2.ed. Cambridge: Cambridge University Press, 1942.

VARELA, F. J.; THOMPSON, E.; ROSCH, E. The embodied mind: cognitive science and human experience. Cambridge, MA: The MIT Press, 2016.

VECCHI, D. Entrenchment implies that physiological and developmental processes are not organismbound but still organism-centric. Adaptive Behavior, v. 28, n. 1, p. 33-34, 2019.

VRBA, E. S. The fossil record of African antelopes (Mammalia, Bovidae) in relation to human evolution and paleoclimate. In: VRBA E. S.; DENTON, G. H.; PARTRIDGE, T. C.; BURCKLE, L. H. (Eds.) Paleoclimate and evolution, with emphasis on human origins. New Haven: Yale University Press, 1005. p. 385-424.

WADDINGTON, C. H. Discussion. In: MOORHEAD, P. S.; KAPLAN, M. M. (Eds.) Mathematical challenges to neodarwinian interpretation of evolution. Philadelphia: Wistar Institute, 1967.

WAGNER, A. Arrival of the fittest. New York: Oneworld Publications, 2015.

WHEELER, M. Autopoiesis, enactivism, and the extended mind. Proceedings of the International Conference on the Synthesis and Simulation of Living Systems, v. 11, p. 819, 2008.

WHEELER, M. In defense of extended functionalism. In: MENARY, R. (Ed.) The extended mind. Cambridge, MA: The MIT Press, 2010. p. 245-270.

WILSON, R. A. Boundaries of the mind: the individual in the fragile sciences-cognition. Cambridge: Cambridge University Press, 2004.

WRIGHT, S. The shifting balance theory and macroevolution. Annual Review of Genetics, v. 16, p. 01$19,1982$.

YAMAUCHI, H.; DEACON, T. D.; OKANOYA, K. The myth surrounding the ban by Société de Linguistique de Paris. The Evolution of Language, v. 1, p. 569-570, 2012.

\section{NOTES}

1 Acheulean (or mode 2) tools are oval and pear-shaped hand axes typically found with Homo erectus remains and dating from Lower to Middle Palaeolithic. They are more advanced than the Mode 1 tools (e.g. Oldowan) but they lack the sophistication of Mode 3 tools (e.g. Mousterian). 